\title{
FACTORS AFFECTING TAX MORALE: AN EMPIRICAL STUDY ON STUDENTS OF AKSARAY AND ÇUKUROVA UNIVERSITY
}

\author{
Orçun $\mathbf{A V C l}^{1}$
}

\author{
Gülin TABAKAN²
}

\author{
Gülsen KIRAL ${ }^{3}$
}

\begin{abstract}
Tax morale is a multi-dimensional concept. The concept that has an individual and social dimension affects the attitudes and behaviors of individuals against taxes. As tax morale is perceived differently from one society to another and its effect can be different based on society, it may also show differences in family structures, societal ties and environmental relationships of individuals within the same society. The aim of this study is to compare tax morale levels of the students of department of Public Finance and department of Economics at Aksaray University and Çukurova University and determine the socio-cultural factors and some demographic factors which affect the tax morale of the students. The tax morale score of the students is found 3,57. Tax morale score is interpreted when it is low as the average approaches 1 (strongly disagree) and it is high as the avarage approaches 5 (strongly agree). Accordingly, tax morale level of students $(3,57)$ is above average. As a result of empirical study, the comparison results between the tax morale scores of different university students indicate that: Tax morale of students of Aksaray University is higher than the students of Çukurova University and generally tax morale level of female students is higher than male students.
\end{abstract}

Keywords: Tax, Tax Morale, Tax Psychology, Statistical Analysis.

JEL Code: H2O, H29, C10.

\section{Introduction}

In this study, it is aimed to compare the tax morale levels of 535 students studying at the Public Finance and Economics Departments of Aksaray and Çukurova Universities, and to determine some factors affecting the tax morality levels of the students. A questionnaire consisting of 3 sections prepared according to 5-point Likert scale is used in the study. The first part of the questionnaire includes demographic characteristics, the second part, 4 questions about sociocultural statements and the third part, 6 questions about tax morale. With these questions, the attitudes of the students studying in two different universities towards the tax morale are measured. In the evaluation of the questionnaire data, Statistics Package for The Social Sciences (SPSS 18.0) is used. The significance level is 0,05 for statistical analysis.

\footnotetext{
1 Res. Asst. Dr., Aksaray University, Faculty of Economics and Administrative Sciences, Department of Public Finance, orcun.avci@outlook.com

2 Assoc. Prof., Aksaray University, Faculty of Economics and Administrative Sciences, Department of Public Finance, gtabakan@aksaray.edu.tr

3 Assoc. Prof., Çukurova University, Faculty of Economics and Administrative Sciences, Department of Econometrics, gkiral@cu.edu.tr
} 


\section{Theoretical Framework}

Tax morale can be considered as a moral obligation to pay taxes or a belief in contributing to society by paying taxes (Torgler, 2004: 239). Due to the strong evidence that tax morale affects the actual tax payment behavior, finding the determinants of tax morale can help both to understand and fight tax evasion (Doerrenberg \& Peichl, 2013: 293). Tax morale is often defined as the intrinsic motivation to pay taxes. At the same time, tax morale is closely related to tax compliance. There are many factors in shaping tax morale (Luttmer \& Singhal, 2014: 150). Moral norms, trust in state, social pride as well as social, economic and political factors are effective. In addition, socio-psychological factors also shape the attitudes and behaviors of individuals about tax. Human being is by nature a social being and the behavior of other people in society on the shaping of tax morality is also a significant factor (Lillemets, 2010: 238).

\section{Survey Findings}

In this study gender, department and university are used as independent variables and the effects of these variables on tax morale are analyzed. The purpose of this study is two-fold. First, tax morale behaviors of students in Public Finance and Economics of Aksaray and Çukurova Universities are compared. Second, the socio-cultural factors and some demographic factors which affect the tax morale of the students are determined. The data obtained from the study are analyzed with some statistical methods such as frequency distribution, reliability analysis, Kolmogorov-Smirnov test, Kruskal Wallis $\mathrm{H}$ test.

Of the students who participated to survey, 47,5\% are from Aksaray University, 52,5\% are from Çukurova University, 39,6\% are male, $60,4 \%$ are female, $49 \%$ are studying in department of Public Finance and $51 \%$ are studying in department of Economics. The scale's reliability is measured using Cronbach alpha reliability coefficient. The coefficient for all items is found to be 0,874 . Moreover, the coefficient for the 'responses of questions about tax morale' subscale is found to be 0,904 . A Cronbach's $\alpha$ of greater than or equal to 0,6 is interpreted as acceptable level of reliability in most social science research situations. So the values of the coefficients show that the survey is highly reliable. According to the Kolmogorov-Smirnov test result, it is found that the tax morale is not normally distributed (sig: ,000 < 0,05). Thus, Kruskal Wallis $\mathrm{H}$ test is used to compare group means of the sub-dimensions of variables University_Department and University_Gender in Table 1. 


\section{Table 1. Comparisons of the Responses of Tax Morale Questions for the Variables University_Department and University_Gender-Kruskal Wallis H Test Results}

\begin{tabular}{|c|c|c|c|c|c|c|c|c|}
\hline Statements & University_Department & $\mathbf{N}$ & $\begin{array}{l}\text { Mean } \\
\text { Ranks }\end{array}$ & & University_Gender & $\mathbf{N}$ & Mean Ranks & \\
\hline \multirow{4}{*}{$\begin{array}{l}\text { Paying taxes is } \\
\text { an important } \\
\text { citizenship duty. }\end{array}$} & Çukurova_Public Finance & 136 & 125,18 & \multirow{4}{*}{$\begin{array}{c}\text { Chi } \\
\text { Square: } \\
\text { 181,382 } \\
\text { sd: } 3 \\
\text { Sig: ,000 }\end{array}$} & Çukurova_Female & 164 & 224,94 & \multirow{4}{*}{$\begin{array}{c}\text { Chi } \\
\text { Square: } \\
85,014 \\
\text { sd: } 3 \\
\text { Sig: } \\
, 000\end{array}$} \\
\hline & Çukurova_Economics & 145 & 297,49 & & Çukurova_Male & 117 & 198,88 & \\
\hline & Aksaray_Public Finance & 126 & 346,68 & & Aksaray_Female & 159 & 339,41 & \\
\hline & Aksaray_Economics & 128 & 308,89 & & Aksaray_Male & 95 & 307,94 & \\
\hline \multirow{4}{*}{$\begin{array}{l}\text { If I evade taxes, } \\
\text { and if people } \\
\text { around me } \\
\text { learn about it, } \\
\text { I would be very } \\
\text { ashamed. }\end{array}$} & Çukurova_Public Finance & 136 & 162,18 & \multirow{4}{*}{$\begin{array}{c}\text { Chi } \\
\text { Square: } \\
\text { 92,766 } \\
\text { sd: } 3 \\
\text { Sig: ,000 }\end{array}$} & Çukurova_Female & 164 & 241,24 & \multirow{4}{*}{$\begin{array}{c}\text { Chi } \\
\text { Square: } \\
33,625 \\
\text { sd: } 3 \\
\text { Sig: } \\
\text {,000 }\end{array}$} \\
\hline & Çukurova_Economics & 145 & 303,52 & & Çukurova_Male & 117 & 226,52 & \\
\hline & Aksaray_Public Finance & 126 & 311,24 & & Aksaray_Female & 159 & 318,89 & \\
\hline & Aksaray_Economics & 128 & 297,63 & & Aksaray_Male & 95 & 280,11 & \\
\hline \multirow{4}{*}{$\begin{array}{l}\text { Paying taxes as } \\
\text { a taxpayer is } \\
\text { an indicator of } \\
\text { being moral. }\end{array}$} & Çukurova_Public Finance & 136 & 166,17 & \multirow{4}{*}{$\begin{array}{c}\text { Chi } \\
\text { Square: } \\
89,425 \\
\text { sd: } 3 \\
\text { Sig: ,000 }\end{array}$} & Çukurova_Female & 164 & 227,52 & \multirow{4}{*}{$\begin{array}{c}\text { Chi } \\
\text { Square: } \\
39,093 \\
\text { sd: } 3 \\
\text { Sig: } \\
\text {,000 }\end{array}$} \\
\hline & Çukurova_Economics & 145 & 290,92 & & Çukurova_Male & 117 & 234,79 & \\
\hline & Aksaray_Public Finance & 126 & 320,61 & & Aksaray_Female & 159 & 316,32 & \\
\hline & Aksaray_Economics & 128 & 298,44 & & Aksaray_Male & 95 & 297,91 & \\
\hline \multirow{4}{*}{$\begin{array}{l}\text { The low tax } \\
\text { morale of a } \\
\text { society forces } \\
\text { the state in fiscal } \\
\text { and economic } \\
\text { terms. }\end{array}$} & Çukurova_Public Finance & 136 & 161,32 & \multirow{4}{*}{$\begin{array}{c}\text { Chi } \\
\text { Square: } \\
\text { 99,642 } \\
\text { sd: } 3 \\
\text { Sig: ,000 }\end{array}$} & Çukurova_Female & 164 & 234,34 & \multirow{4}{*}{$\begin{array}{c}\text { Chi } \\
\text { Square: } \\
52,588 \\
\text { sd: } 3 \\
\text { Sig: } \\
\text {,000 }\end{array}$} \\
\hline & Çukurova_Economics & 145 & 284,72 & & Çukurova_Male & 117 & 211,91 & \\
\hline & Aksaray_Public Finance & 126 & 322,79 & & Aksaray_Female & 159 & 322,38 & \\
\hline & Aksaray_Economics & 128 & 308,46 & & Aksaray_Male & 95 & 304,17 & \\
\hline \multirow{4}{*}{$\begin{array}{l}\text { Tax morale is } \\
\text { an important } \\
\text { indicator of } \\
\text { development. }\end{array}$} & Çukurova_Public Finance & 136 & 147,28 & \multirow{4}{*}{$\begin{array}{c}\text { Chi } \\
\text { Square: } \\
\text { 129,628 } \\
\text { sd: } 3 \\
\text { Sig: ,000 }\end{array}$} & Çukurova_Female & 164 & 226,45 & \multirow{4}{*}{$\begin{array}{l}\text { Chi } \\
\text { Square: } \\
66,341 \\
\text { sd: } 3 \\
\text { Sig: } \\
, 000\end{array}$} \\
\hline & Çukurova_Economics & 145 & 288,51 & & Çukurova_Male & 117 & 211,34 & \\
\hline & Aksaray_Public Finance & 126 & 337,52 & & Aksaray_Female & 159 & 334,17 & \\
\hline & Aksaray_Economics & 128 & 304,61 & & Aksaray_Male & 95 & 298,77 & \\
\hline \multirow{4}{*}{$\begin{array}{l}\text { The fiscal and } \\
\text { economic } \\
\text { education that } \\
\text { I have acquired } \\
\text { is improving the } \\
\text { tax morale. }\end{array}$} & Çukurova_Public Finance & 136 & 144,76 & \multirow{4}{*}{$\begin{array}{c}\text { Chi } \\
\text { Square: } \\
\text { 137,866 } \\
\text { sd: } 3 \\
\text { Sig: ,000 }\end{array}$} & Çukurova_Female & 164 & 236,18 & \multirow{4}{*}{$\begin{array}{c}\text { Chi } \\
\text { Square: } \\
\text { 59,359 } \\
\text { Sd:3 } \\
\text { Sig: } \\
\text {,000 }\end{array}$} \\
\hline & Çukurova_Economics & 145 & 296,55 & & Çukurova_Male & 117 & 204,74 & \\
\hline & Aksaray_Public Finance & 126 & 343,17 & & Aksaray_Female & 159 & 324,33 & \\
\hline & Aksaray_Economics & 128 & 292,59 & & Aksaray_Male & 95 & 306,57 & \\
\hline
\end{tabular}

The results on Table 1 show that there is a significant difference in sub-dimensions of variables University_Department and University_Gender based on the statements (sig: <0,05). Results of analysed mean ranks belonging to the groups show that Public Finance students have more tax morale than Economics students at Aksaray University from the perspective of tax marale questions. Similarly, Table 1 shows that Economics students have more tax morale than Public Finance students at Çukurova University. Table 1 shows that the difference is statistically significant in the statements based on gender. Results of analysed mean ranks belonging the groups show that females have more tax morale than males from the perspective of statements for both Aksaray University and Çukurova Universities. Furthermore, the mean rank of female students of Aksaray University about the statements related tax morale is the highest. 
Table 2. Kruskal Wallis H Test Results Related with Socio-Cultural Factors-University_ Gender and University_Department

\begin{tabular}{|c|c|c|c|c|c|c|c|c|}
\hline Statements & University_Department & $\mathbf{N}$ & $\begin{array}{l}\text { Mean } \\
\text { Ranks }\end{array}$ & & University_Gender & $\mathbf{N}$ & Mean Ranks & \\
\hline \multirow{4}{*}{ SC1 } & $\begin{array}{c}\text { Çukurova_Public } \\
\text { Finance }\end{array}$ & 136 & 194,85 & \multirow{4}{*}{$\begin{array}{c}\text { Chi } \\
\text { Square: } \\
54,924 \\
\text { sd: } 3 \\
\text { Sig: ,000 }\end{array}$} & Çukurova_Female & 164 & 229,50 & \multirow{4}{*}{$\begin{array}{c}\text { Chi } \\
\text { Square: } \\
39,159 \\
\text { sd: } 3 \\
\text { Sig: ,000 }\end{array}$} \\
\hline & Çukurova_Economics & 145 & 262,63 & & Çukurova_Male & 117 & 230,28 & \\
\hline & Aksaray_Public Finance & 126 & 321,02 & & Aksaray_Female & 159 & 307,54 & \\
\hline & Aksaray_Economics & 128 & 299,61 & & Aksaray_Male & 95 & 314,74 & \\
\hline \multirow{4}{*}{ SC2 } & $\begin{array}{l}\text { Çukurova_Public } \\
\text { Finance }\end{array}$ & 136 & 113,64 & \multirow{4}{*}{$\begin{array}{c}\text { Chi } \\
\text { Square: } \\
211,574 \\
\text { sd: } 3 \\
\text { Sig: ,000 }\end{array}$} & Çukurova_Female & 164 & 220,38 & \multirow{4}{*}{$\begin{array}{l}\text { Chi } \\
\text { Square: } \\
\text { 101,615 } \\
\text { sd: } 3 \\
\text { Sig: ,000 }\end{array}$} \\
\hline & Çukurova_Economics & 145 & 298,53 & & Çukurova_Male & 117 & 193,15 & \\
\hline & Aksaray_Public Finance & 126 & 343,53 & & Aksaray_Female & 159 & 343,53 & \\
\hline & Aksaray_Economics & 128 & 323,09 & & Aksaray_Male & 95 & 315,97 & \\
\hline \multirow{4}{*}{ SC3 } & $\begin{array}{c}\text { Çukurova_Public } \\
\text { Finance }\end{array}$ & 136 & 319,27 & \multirow{4}{*}{$\begin{array}{c}\text { Chi } \\
\text { Square: } \\
30,340 \\
\text { sd: } 3 \\
\text { Sig: ,005 }\end{array}$} & Çukurova_Female & 164 & 269,95 & \multirow{4}{*}{$\begin{array}{c}\text { Chi } \\
\text { Square: } \\
2,127 \\
\text { sd: } 3 \\
\text { Sig: ,546 }\end{array}$} \\
\hline & Çukurova_Economics & 145 & 222,89 & & Çukurova_Male & 117 & 268,95 & \\
\hline & Aksaray_Public Finance & 126 & 254,00 & & Aksaray_Female & 159 & 255,79 & \\
\hline & Aksaray_Economics & 128 & 278,41 & & Aksaray_Male & 95 & 283,90 & \\
\hline \multirow{4}{*}{ SC4 } & $\begin{array}{c}\text { Çukurova_Public } \\
\text { Finance }\end{array}$ & 136 & 159,50 & \multirow{4}{*}{$\begin{array}{c}\text { Chi } \\
\text { Square: } \\
115,225 \\
\text { sd: } 3 \\
\text { Sig: ,000 }\end{array}$} & Çukurova_Female & 164 & 225,37 & \multirow{4}{*}{$\begin{array}{l}\text { Chi } \\
\text { Square: } \\
79,303 \\
\text { sd: } 3 \\
\text { Sig: ,000 }\end{array}$} \\
\hline & Çukurova_Economics & 145 & 266,66 & & Çukurova_Male & 117 & 199,97 & \\
\hline & Aksaray_Public Finance & 126 & 337,25 & & Aksaray_Female & 159 & 330,86 & \\
\hline & Aksaray_Economics & 128 & 316,64 & & Aksaray_Male & 95 & 320,18 & \\
\hline
\end{tabular}

The socio-cultural factors affecting the tax morale such as 'the level of trust in government (SC1)', 'a sense of civic virtue (SC2)', 'the level of accepted ruling party (SC3)' and 'religion belief (SC4)' on tax morale have been analyzed in this study. In Table 2, Kruskal-Wallis $\mathrm{H}$ test is used to measure differences in terms of socio-cultural factors based on participants' gender and department. As can be seen in Table 2: since the $p$ values of all the statements are less than 0,05 at $95 \%$ confidence interval of the difference (except for SC3), these differences are assessed as a statistically significant $(p<0,05)$. Moreover, the socio-cultural factors have all statistically significant effects on tax morale based on participants' department.

\section{Conclusion}

Tax morale is a phenomenon affected from many factors such as economic, social, cultural and demographic factors. The study aims to investigate the factorsinfluencing students' tax morale. The study compares male and female scores for Aksaray and Çukurova Universities. From Table 1 , it is thought that female scores would be significantly higher than male scores, significance being defined here as higher scores for all statements. Results of analysed mean ranks belonging to the University_Department show that the students of department of Public Finance have more tax morale than the students of department of Economics at Aksaray University from 
the perspective of tax questions. Similarly, Table 1 shows that the students of department of Economics have more tax morale than the students of department of Public Finance at Çukurova University.

In general, tax morale of students of Aksaray University is higher than the students of Çukurova University and the tax morale of female students is higher than male students for both universities. In conclusion, it has been determined that while the mean rank of female students at Aksaray University about the statements is the highest, the mean rank of the students for Economics department at Çukurova University about the statements is the lowest.

\section{References}

Doerrenberg, P. \& Peichl, A. (2013). "Progressive Taxation and Tax Morale", Public Choice, 155(34), pp. 293-316.

Lillemets, K. (2010). "Tax Morale, Influencing Factors, Evaluation Opportunities and Problems: The Case of Estonia", Estonian Discussions on Economic Policy, 18, pp. 233-252.

Luttmer, E. F. P. \& Singhal, M. (2014). “Tax Morale”, Journal of Economic Perspectives, 28 (4), Fall, pp. 149-168.

Torgler, B. (2004). “Tax Morale in Asian Countries", Journal of Asian Economics, 15(2), pp. 237-266. 